\title{
ORGANIZATION-LEVEL INTERVENTIONS IN MITIGATING THE BURDEN OF WORKPLACE CONFLICTS
}

\author{
UWIMPUHWE Dorothée \\ Master of Business Administration (Management) \\ Tel: +250788573738 \\ uwimpuhwe.doroth@gmail.com
}

\begin{abstract}
Conflicts are unavoidable at workplace and become a burden in case managers and leaders ignore their roots. Despite conflicts appear annoying and destructive, they sometimes provide a positive way to strengthen employees- manager's relationship and reveal the means to solving repetitive organization issues occurring at workplace. Conflicts within organizational settings are therefore an interesting topic to be discussed by researchers or scholars so that they can propose adequate solutions to handle them. This paper identifies conflicts handling styles recommended for managers and leaders to address and mitigate the burden of workplace conflicts whose outcomes are burnout, psychological and physical illness, absenteeism, lost productivity (from being unwell in the workplace) and turnover resulting from personality, diversity, perception, culture, occupational stress, etc., based on the types (task, process and relationship conflicts) with proper diagnosis and organizational- level interventions of such conflicts as compared to non-intervention controls. The researcher concluded that as negative outcomes of workplace conflicts are unpredictable, it is better to prevent conflicts than to cure them.
\end{abstract}

KEYWORDS: Workplace Conflict, Task Conflict, Relationship Conflict, Process Conflict. 


\section{INTRODUCTION}

Conflict occurs between people in all kinds of human relationships and in all social settings. Because of the wide range of potential differences among people, the absence of conflicts usually signals the absence of meaningful interaction. Conflict by itself is neither good nor bad. However, the manner in which conflict is handled determines whether it is constructive or destructive (Deutsch \& Coleman, 2000). Conflict is defined as an incompatibility of goals or values between two or more parties in a relationship, combined with attempts to control each other and antagonistic feelings toward each other. The incompatibility may exist in reality or may only be perceived by the parties involved (Fisher, 1997).

\section{Statement of the Problem}

Conflict is a dysfunctional outcome resulting from poor communication, a lack of openness and trust between people, and the failure of managers to be responsive to the needs and aspirations of their employees. The view that all conflict is bad certainly offers a simple approach to looking at the behavior of people who create conflict. It is needed to merely direct our attention to the causes of conflict and correct those malfunctions to improve group and organizational performance (Robbins \& Judge, 2013).

According to Dewey (1922/1957), Conflict is the gadfly to thought. It stirs us to observation and memory. It instigates us to invention. It shocks us out to sheep-like passivity, and sets us at noting and contriving. He observed that when the relationship between human beings and environment is interrupted by obstacles or conflict, individuals must use their intelligence to readapt through a change in their accustomed modes of conduct and belief. In other words, an individual should examine a conflict situation to discover the various actions possible and choose the one that is most effective. Conflicts in general are inevitable and are found in daily human interactions. Many types of relationships such as marriages, families, churches, ethnic groups, nations and workplaces suffer from conflicts (Deutsch, Coleman \& Marcus 2006; Afful-Broni, 2012).

Pondy (1967) observed that organization theories that do not admit conflict provide poor guidance in dealing with problems of organizational efficiency, stability, governance, and change, for conflict within and between organizations, for conflict is intimately related as either symptom, cause, or effect, to each of these problems. It has been stipulated by Baron and Greenberg (1990) that organizational conflict is an important topic for both managers and for scientists interested in understanding the nature of organizational behavior and organizational processes. Organizational conflict may be classified on the basis of its sources or antecedent conditions. Accordingly, it was classified as affective conflict, substantive conflict, conflict of interest, conflict of values, cognitive conflict, realistic versus nonrealistic conflict, institutionalized versus non institutionalized conflict, retributive conflict, misattributed conflict, and displaced conflict (Rahim, 2001).

The interactionist view does not propose that all conflicts are good. Rather, functional conflict supports the goals of the group and improves its performance and is, thus, a constructive form of conflict. A conflict that hinders group performance is a destructive or dysfunctional 
conflict. The evidence indicates we need to look at the type of conflict whether it is connected to task, relationship, or process. Task conflict relates to the content and goals of the work. Relationship conflict focuses on interpersonal relationships. Process conflict relates to how the work gets done. Studies demonstrate that relationship conflicts are almost always dysfunctional. Recent reviews have shown that task conflicts are usually just as disruptive as relationship conflicts (Robbins \& Judge, 2013)

Based on the researcher's experience, relationship conflicts are the most destructive. They are main barriers to employee productivity and performance reducing their morale, commitment and engagement. What do you think can happen when two or more employees have misunderstandings among themselves or between themselves and their employers regardless their cause? What if the concerned parties are not eager for resolution of conflict matter? Let the researcher reveal to you what always happen. Normally, within any conflict occurring there are two conflicting parties and the one who feels victimized changes his/her behavior. This is revealed by the way he/she is satisfied or committed toward work to be performed. You can also identify various unjustified retardation at work, pretending illness or sickness, headaches, several sleepless nights leading even to long absences that can be translated into turnover. This is the main reason why the researcher is motivated to designing this research paper. 


\section{Conceptual framework}

Figure 1- Diagnosis and organizational- level interventions

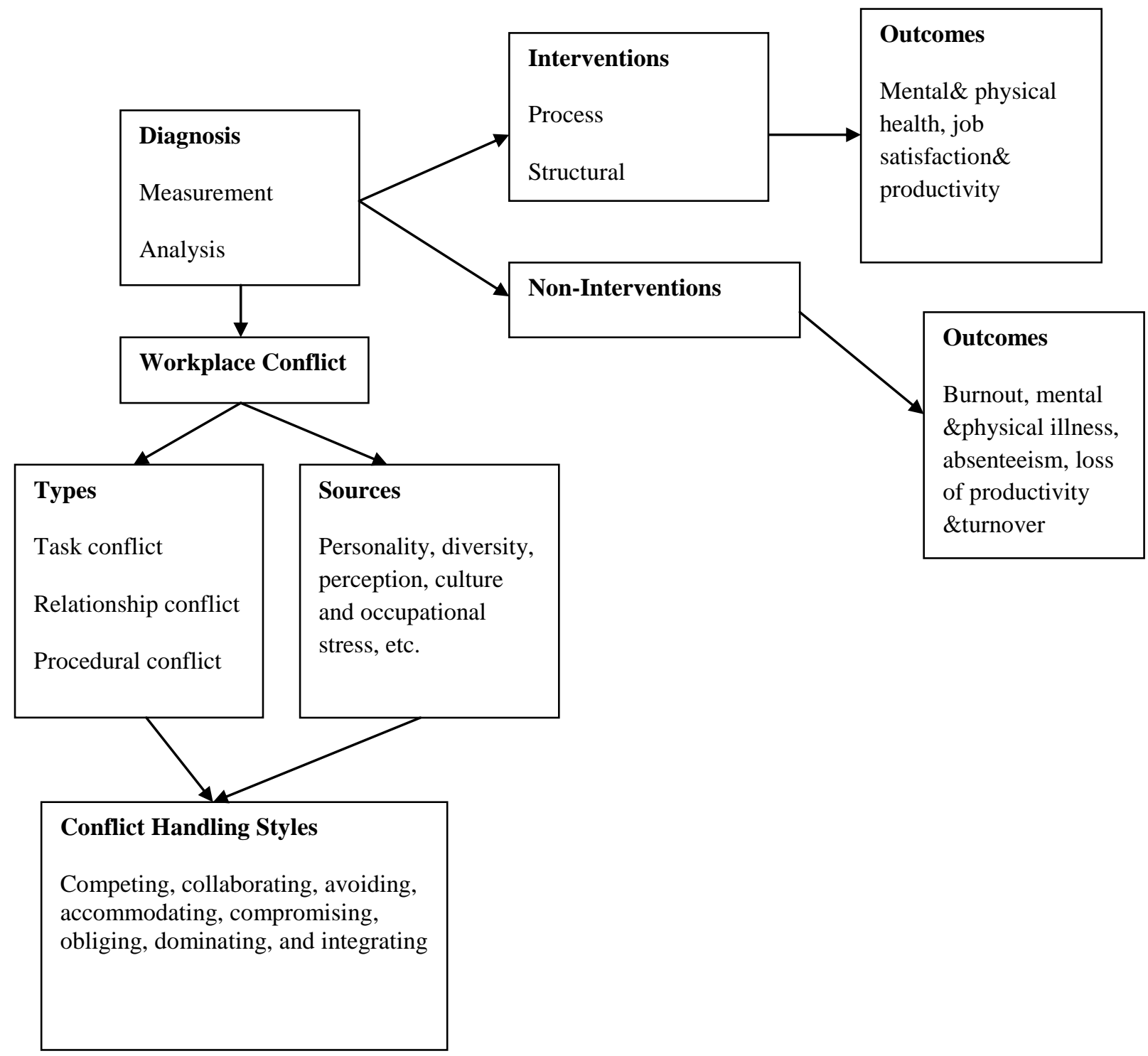

Source: Researcher's construct (November, 2015)

\section{REVIEW OF RELATED LITERATURE}

The review of related literature describes the key concepts extracted from different books, journals, and other research reviews that provide clear understanding of the researcher's topic. It explains in details the key concepts of this paper namely workplace conflict, task conflict, relationship conflict, and process conflict. 


\section{Workplace Conflict}

Literature on conflict according to Buss (2009) does not provide a uniform definition. For instance, Wise (2000) regarded conflict as two pieces of matter trying to occupy the same space at the same time. Again, Laue (1992) described conflict as an escalated natural competition between two or more parties about scarce resources, power, and prestige and these parties believe that they have incompatible goals so they aim at neutralizing, gain advantage, injure or destroy one another.

Most conflicts are normally linked with negativities and so are workplace conflicts. Usually, workplace conflict occurs when there are misunderstandings about how a task or a job is to be done (process conflict), the content of the task (task conflict) or the interactions among people or working colleagues (relationships conflict). The outcomes of these misunderstandings are largely known to be negative and disastrous as they may result in working colleagues fighting, not greeting each other, not talking to each other and quarreling, among others. Relationships at the workplace get strained and affect the attitude of employees towards work and this affects productivity as well as quality and other elements of production thereby making the achievement of the organizational goal very difficult. Workplace conflict usually results in high rate of absenteeism among employees and badly managed conflict causes stress, reduces confidence levels, and produces anxiety and frustrations that result in lowered job motivation, humiliation and physical illness (Riaz \& Junaid, 2011).

According to Buss (2009), conflicts at the workplace result in psychological and physical distress among employees that even affects their family and friends. This consequently worsens medical conditions of employees, damages quality of work life, gives impression of ineffectiveness at work, increases labor turnover and above all declines productivity. Workplace conflict differs from other conflicts in that in the workplace, employees are obliged to work together (they are interdependent) whether they are experiencing conflicts or not in order to achieve organizational goals (Rahim, 2010). Whereas Dana (2001) explained that workplace conflict is a condition between or among workers whose jobs are interdependent, who feel angry, who perceive the other as being at fault and who act in ways that cause a problem, De Dreu and Gelfand (2007) argued that workplace conflict may arise because of scarce resources (e.g. time, status, budgets) or values (such as political preferences, beliefs, religion, moral and social values). Ramani and Zhimin (2010) further reported that organizational conflict occurs when members engage in activities that are incompatible with that of colleagues within their network, members of other groups or unaffiliated individuals who utilize the services or products of the organization.

\section{Sources of conflicts}

Fajana (2000) identifies two sources of conflict and they include:

Internal Sources: This is so called because they refer to factors which are inherent within the framework of an organization. Fajana (2000) states that the major prime factor of internal sources of conflict is the opposing interests of industrial actors. These divergent interests 
will bring about conflict in attempts by the two parties in organizations to try to share what Ajibade (2004) calls industrial cake.

The External Sources: These are so called because they are outside the four walls of an organization. They may occur when the third party intervention to industrial dispute becomes one sided or biased (Fajana, 2000). According to the researcher's experience, there exist external sources of workplace conflicts that are more destructive than you can imagine. They are like carried burden on employees' necks. They are exacerbated by managers/leaders that close eyes on what is going on and provide inadequate explanation regarding any unexpected change within organization so that appropriate interventions may be put into consideration. For instance, labor conflicts rooted in economic pressures where employees wake up in early morning and get informed about new unfavorable wage policy they never contributed to its elaboration to benefit both economic factors leading to infinite complaints and mob violence which deteriorate the overall organization system and hence its performance.

\section{Types of conflicts}

A commonly used model to understand conflict types focuses on interpersonal, intergroup and intra-group conflict within the workplace (Jehn \& Bendersky, 2003; Nelson, 1989). A resultant output is the classification of affective and substantive conflict, also referred to as relationship and task conflict (Simons \& Peterson, 2000, Pinkley, 1990). A third dimension of conflict as also evident in the literature, is procedural or process conflict, which entails the differences of opinion pertaining to the distribution of work responsibilities (Chaudhry \& Asif, 2015).

\section{Handling Conflicts Styles}

Depending on the situation, decision making on the handling conflict styles will base on the following:

Competing Style: It is used when one person seeks to satisfy his or her own interests regardless of the impact on the other parties to the conflict (Robbins \& Judge, 2013).

Collaborating Style: It is used when parties in conflict each desires to fully satisfy the concerns of all parties; there is cooperation and a search for a mutually beneficial outcome. The parties intend to solve a problem by clarifying differences rather than by accommodating various points of view where a win-win solution that allows both parties' goals to be completely achieved is focused on (Robbins \& Judge, 2013).

Avoiding Style: It is used when a person may recognize a conflict exists and want to withdraw from or suppress it (Robbins \& Judge, 2013).

Accommodating Style: It is used when a party who seeks to appease an opponent may be willing to place the opponent's interests above his or her own, sacrificing to maintain the relationship (Robbins \& Judge, 2013).

Compromising Style: It is used when there is no clear winner or loser. Rather, there is a willingness to ration the object of the conflict and accept a solution that provides incomplete 
satisfaction of both parties' concerns. The distinguishing characteristic of compromising, therefore, is that each party intends to give up something (Robbins \& Judge, 2013).

Obliging Style: This style is useful when a party is not familiar with the issues involved in a conflict, or the other party is right, and the issue is much more important to the other party. This style may be used as a strategy when a party is willing to give up something with the hope of getting some benefit from the other party when needed. This style is inappropriate if the issue involved in a conflict is important to the party, and the party believes that he or she is right. It is also inappropriate when a party believes that the other party is wrong or unethical (Rahim, 2001).

Dominating Style: This style is appropriate when the issues involved in a conflict are important to the party, or an unfavorable decision by the other party may be harmful to this party. A supervisor may have to use it to deal with subordinates who are very assertive or who do not have expertise to make technical decisions. This is also effective in dealing with the implementation of unpopular courses of action (Rahim, 2001).

Integrating Style: This is useful for effectively dealing with complex problems when one party alone cannot solve the problem (i.e., synthesis of ideas is needed to come up with a better solution to a problem), this style is appropriate. This can be done provided that there is enough time for problem solving. Lawrence and Lorsch (1967a) found this mode (style) to be more effective than others in attaining integration of the activities of different subsystems of an organization (Rahim, 2001).

\section{How to mitigate workplace conflicts}

In order to address and mitigate the burden of workplace conflict whose outcomes are burnout, psychological and physical illness, absenteeism, (lost productivity from being unwell in the workplace) and turnover resulting from personality, diversity, perception, culture and occupational stress, the diagnosis and organizational- level interventions as compared to nonintervention controls are the following:

The diagnosis conflict can be performed by such methods as self-reports, observation, and interviews and the data collected will be analyzed to find out what conflict handling style is required and the source of conflict occurred. A comprehensive diagnosis conflict involves the measurement of the styles of handling conflict used by the organizational members to deal with different situations, factors that affect the styles of handling conflict such as personality, bases of power, organizational culture, referent role, and gender and effectiveness of the individual members of an organization while an analysis of the preceding diagnostic data should provide the information on the styles of handling conflict utilized by the members of various units, departments, or divisions and whether they deviated from the national norms significantly, whether organizational members are using appropriate behavioral styles to deal with different situations effectively and relationships of the styles to situations and individual effectiveness (Rahim, 2001). 
A proper diagnosis should indicate whether there is any need for intervention and the type of intervention required. There are two basic approaches to intervention in conflict; process and structural. Process intervention attempts to improve organizational effectiveness by changing members' styles of handling conflict whereas structural intervention attempts to improve the organizational effectiveness by changing the organization's structural design characteristics, which include differentiation and integration mechanisms, hierarchy, procedures, reward system, and so on (Rahim \& Bonoma, 1979).

Considering the nature, causes, and consequences of conflict, in case conflict is caused by resource allocation, negotiation is often used to it. Negotiation can be defined as a process that occurs when two or more parties decide how to allocate scarce resources (Bazerman, et al., 2000). There are two general approaches to negotiation; distributive bargaining and integrative bargaining (Lewicki, Saunders, \& Barry, 2009)

Distributive bargaining, a negotiation that seeks to divide up a fixed amount of resources; a win-lose situation (Robbins\& Judge, 2013).

Integrative bargaining, a negotiation that seeks one or more settlements that can create a win-win solution (Robbins\& Judge, 2013).

Occasionally, however, individuals or group representatives reach a stalemate and are unable to resolve their differences through direct negotiations. In such cases, they may turn to a third party to help them find a solution. There are three basic third-party roles: mediator, arbitrator, and conciliator (Robbins\& Judge, 2013).

Let's take examples of an organizational level interventions based on task, relationship, and procedural conflict types:

\section{Task conflict}

Task conflicts arise when there are disagreements among group members about the content of the tasks being performed, including differences in viewpoints, ideas and opinions (Jehn, 1995). From a constructive perspective, task conflict enhances creativity, members get alternate ideas for the task at hand, it stimulates discussion and constructive feedback from the group members is likely to flow in, so as a result the group performs better. It has also been observed that availability of varied perspectives helps the workplace teams to offer better productivity as the knowledge of different employees is assimilated to perform the allocated tasks (Wlodarczyk, 2010).

Task conflict has been associated with several beneficial effects such as improving the use of debate within a team (Jehn et al., 1999), which results in quality ideas and innovation (Amason, 1996; West \& Anderson, 1996) and leads to better service delivery (Tjosvold, Dann \& Wong, 1992). In addition, studies have shown that task conflict can also be associated with several harmful effects, such as job dissatisfaction, lack of team work (Kabanoff, 1991; Jehn, et $a l, 1997)$, and increased anxiety (Jehn, 1997). 
Two types of intervention, process and structural, are available for the management of task conflict. The process intervention is role analysis designed to improve overall organizational effectiveness by intervening at individual, group, and intergroup levels. A model of role analysis is utilized to examine the purpose of the role, its prescribed and discretionary elements, and its relationship with other roles. The role analysis should ideally start with the top manager of the system being changed (Dayal\& Thomas, 1968).

Job design, job enrichment, and job rotation are the proposed structural interventions for managing task conflict:

Job Design specifies the contents of jobs in order to satisfy work requirements and meet the personal needs of the job holder, thus increasing levels of employee engagement. This involves the planning of the job, including its contents, the methods of performing the job, and how it relates to other jobs in the organization (Armstrong \& Taylor,2014).

Job enrichment is the second approach which involves changing the job to make it satisfying. Herzberg's two-factor theory provided real impetus to job enrichment (Herzberg, Mausner, \& Snyderman, 1959). Herzberg's approach to job enrichment involves improvement of the motivation factors, such as achievement, recognition, responsibility, advancement, and opportunity for growth. This approach is based on the assumption that job enrichment increases job satisfaction, which, in turn, increases motivation and better performance.

Another approach to job enrichment, recently developed by Hackman and Oldham (1980); their approach attempts to make jobs more meaningful by increasing or adding certain core job characteristics, such as skill variety, task identity, task significance, autonomy, and feedback .These dimensions are positively related to motivation, satisfaction, and quality of work and negatively related to turnover and absenteeism. The five core dimensions can be described as follows:

1. Skill variety. This refers to the degree to which a job requires a variety of activities that involve the use of a number of different skills and talents of employees.

2. Task identity. This refers to the degree to which the job requires an employee to perform a complete piece of work; that is, doing a job from beginning to end with a visible outcome.

3. Task significance. This refers to the degree to which the job has an impact on the lives or work of other people within or outside the organization.

4. Autonomy. This refers to the degree to which the job provides freedom, independence, and discretion to the employee in scheduling his or her work and in determining the procedures to be used in carrying it out.

5. Feedback. This refers to the amount of information that results from the performance of a job by an employee about how well she or he is performing. 
Job Rotation is used if employees suffer from overroutinization of their work. It is also the periodic shifting of an employee from one task to another with similar skill requirements at the same organizational level (also called cross-training) (Robbins \& Judge, 2013).

In process intervention, an organization development technique, such as team building also can be used. It puts emphasis on group learning rather than individual learning. Team building is a planned strategy to bring about changes in the attitudes and behavior of the members of an organizational group (or team), whether permanent or temporary, to improve the group's overall effectiveness (Dyr, 1987).

According to Rahim (2001), the structural changes that can make a group more cohesive and homogeneous are:

1. Change group membership. When a new member joins a group, the level of conflict may be significantly affected if the newcomer is specifically selected for her or his differing beliefs, training, and experiences. The manager can reduce conflict by transferring one or more conflicting members to other units.

2. Changing the group size. The potential for conflict increases as the size of the group is increased. A literature review by Gist, Locke, and Taylor (1987) suggest that relatively small groups tend to be more efficient. Therefore, size of the group should not be increased just for the purpose of generating conflict.

3. Altering difficulty and variability of the task. The amount of conflict may be reduced by redefining and restructuring task and reducing the interrelationships among tasks performed by different members.

4. Altering the reward system. A reward system based on performance can generate productive competition and conflict among group members, which can increase group effectiveness. This is probably one of the effective ways of managing conflict within groups.

5. Altering the rules and procedures and appeals system.

Once all the interventions are provided on time the expected results from them should be individual and group effectiveness, improved communication among individuals and group members, improved employee health, decreased absenteeism and turnover, increased employees self- confidence, job satisfaction , and productivity.

\section{Relationship Conflict}

One can say that relationship conflict relates to disagreements, differences, or incompatibilities between an individual and his or her superior(s), subordinates, or peers (Rahim, 2001). This type of conflict produces negative individual emotions, such as anxiety, mistrust, or resentment (Jehn, 1995), frustration, tension and fear of being rejected by other team members (Murmnigham \& Conlon, 1991). 
In contrast to task conflict, relationship conflict has almost solely been related to negative outcomes, like reduction of team member satisfaction (Jehn, 1995; De Dreu \& Weingart, 2003) and tends to generate a destructive climate, which often fosters negative affections, misattribution and non-collaborative team behavior, that may lead to unsuccessful team functioning and performance (de Dreu \& Weingart, 2003; de Wit, et al., 2012; Smith \& Edmondson, 2008).

There are styles of handling relationship conflict: Competing, collaborating, avoiding, accommodating, compromising (Robbins \& Judge, 2013), obliging, dominating and integrating styles (Rahim, 2001). The literature indicated that the use of integrating style increases job satisfaction, organizational commitment, and performance. In general, integrating and, to some extent, compromising styles are appropriate for handling conflicts involving complex problems, and obliging, dominating, avoiding, and compromising styles are appropriate for dealing with day-to-day or minor problems (Rahim, 2001).

\section{Interventions}

Process intervention that is transactional analysis intervention can enable the members of an organization to improve their communication skills and consequently the styles of handling conflict with superiors, subordinates, and peers. It is designed to improve communication among the members of an organization, to enhance integrating style and, to some extent, the compromising style, and to reduce obliging, dominating, and avoiding styles. Transactional analysis is a tactical tool available to a negotiator that provides a model for controlling our own behavior and for better understanding and influencing the behavior of others (Goldman, 1991).

Structural interventions of a third party also are required to solve relationship conflict. They are:

A mediator is a neutral third party who facilitates a negotiated solution by using reasoning and persuasion, suggesting alternatives, and the like. Mediators are widely used in labor-management negotiations and in civil court disputes. Their overall effectiveness is fairly impressive. But the situation is the key to whether mediation will succeed; the conflicting parties must be motivated to bargain and resolve their conflict. In addition, conflict intensity can't be too high; mediation is most effective under moderate levels of conflict. Finally, perceptions of the mediator are important; to be effective, the mediator must be perceived as neutral and non coercive (Robbins\& Judge, 2013).

Appeal to Authority. Organizations allow members to appeal to a common superior if two or more members, at the same organizational level, fail to resolve their disagreements. The common supervisor can make a decision that will be binding on the two parties involved in conflict, and the supervisor has the right to enforce her or his decisions. This system can work effectively if the supervisor is respected by the conflicting individuals, understands the complexity of the problems, and is able to make a good decision (Rahim, 2001). 
The Ombudsman: An ombudsman is a mediator who ensures fair and just application of the rules and procedures of an organization for the management of conflict between two or more parties. An ombudsman can help to mediate conflict between parties by collecting and providing information on the relevant issues and providing the parties with expert advice and opinion when the parties ask for them. Ombudsmen do not have any authority to make decisions that are binding on the parties, but they can make recommendations (Rahim, 2001).

Other third parties to solve relationship conflict are:

An arbitrator is a third party with the authority to dictate an agreement. Arbitration can be voluntary (requested by the parties) or compulsory (forced on the parties by law or contract). The big plus of arbitration over mediation is that it always results in a settlement. Whether there is a negative side depends on how heavy-handed the arbitrator appears. If one party is left feeling overwhelmingly defeated, that party is certain to be dissatisfied and the conflict may resurface at a later time (Robbins \& Judge, 2013).

A conciliator is a trusted third party who provides an informal communication link between the negotiator and the opponent. Comparing conciliation to mediation in terms of effectiveness has proven difficult because the two overlap a great deal. In practice, conciliators typically act as more than mere communication conduits. They also engage in fact-finding, interpret messages, and persuade disputants to develop agreements (Robbins \& Judge, 2013).

\section{Procedural Conflict}

This refers to disagreement about how a task should be accomplished, individuals' responsibilities and delegation (Jehn \& Mannix, 2001), e.g. when group members disagree about whose responsibility it is to complete a specific duty. Process conflict has been associated with lower morale, decreased productivity (Jehn, 1997) and poor team performance (Jehn, 1999).

Within the context of procedural conflict, the group members may debate over which task should be performed by whom, putting forward different perspectives (Jehn, 1997). It has been further argued that intricate nature of workplace procedures and presence of bureaucratic organizational structure may enhance the chances of such procedural conflict (Jehn \& Bendersky, 2003). Even though allocation of work responsibilities can give rise to conflict among work teams, the management continues to use the tools of job rotation and job enrichment structural interventions to treat this kind of conflict among employees. 


\section{Conclusion}

Conflict is a characteristic of humankind; it is part of day- to- day human life. This attributes to it a great importance for studies and research. But it needs to be managed constructively. When conflict is well understood, it is easier to find ways to predict it, prevent it, transform it, or even resolve it. Research and personal experience show that, when a conflict is avoided, it escalates, worsening thoughts and feelings of inflicted parties to become more negative about it complicating its further cure.

Overall, as compared to no-intervention controls that lead to negative effects such as burnout, mental and physical illness, absenteeism, loss of productivity and turnover, organizational level interventions are very necessary to lead and maintain mental and physical health, job satisfaction and productivity in a sustainable manner in workplace and this is possible if structural changes, modifying goals, redefining relations between authority and responsibility and, if necessary, change the entire organizational structure are put into consideration. As negative outcome of workplace conflict are unpredictable, it is better to prevent conflict than to cure it.

\section{Recommendations}

Conflicting is human nature. As long as different individuals work together, conflicts are unavoidable at workplace. Those conflicts are generally rooted in workers distinction in their age, sex, personality, education, aspirations, tasks, and life goals. However, all workplace conflicts are manageable and controllable. Here are recommendations to managers and leaders so that those conflicts should not be detrimental at workplace:

- Managers and leaders have to make sure that employees contribute to clear conflict policies setting where all peace and trouble makers are rewarded fairly and accordingly;

- Managers and leaders are required to build and maintain good and friendly relationship with employees enabling them to feel at home. Create an environment where every employee is free to express his/her weaknesses which are basis to employee development planning;

- All employees are required to respect one another, respecting their differences and perspectives. Besides, everyone's idea has to be taken as valuable even if its content is not approved by the majority;

- Conflict is like a smoke that starts little and enlarges gradually. Therefore, managers and leaders have to deal with them as they arise with proper styles in conflict resolution;

- As a manager or leader, in conflict resolution process, try to change anyone. Be impartial and humble. Listen carefully and consider every conflicting party's feelings and solve the problem accordingly;

- Managers/leaders, build strong strategies to limit rumors and once they occur, find their source as quick as possible. 


\section{REFERENCES}

Afful-Broni, A. (2012). Conflict management in Ghanaian schools: a case study of the role of leadership of Winneba Senior High School. Journal of Educational Planning \& Administration, 2(2), 65-76.

Ajibade (2004). In Bernard Oladosu Omisore,B.O\& Ashimi Rashidat Abiodun,A.R.(2014). Organizational Conflicts: Causes, Effects and Remedies. International Journal of Academic Research in Economics and Management Sciences, 3( 6): 118-13.

Amason, A. C. (1996). Distinguishing the effects of functional and dysfunctional conflict on strategic decision making: Resolving a paradox for top management teams. Academy of management journal, 39(1): 123-148.

Armstrong, M. \& Taylor,S. (2014).Armstrong's handbook of human resource management practice. 13th Edition.London: Kogan Page Limited.

Baron, R. A., \& Greenberg, J. (1990). Behavior in organizations: Understanding and managing the human side of work (3rd ed.). Needham Heights, MA: Allyn \& Bacon.

Bazerman, M.H., Curhan, J.R., Moore, D.A., \&Valley, K.L. (2000), .Negotiation. Annual Review of Psychology , 51, 279-314.

Buss, H. (2009). Measuring and reducing the cost of conflict at work in UNHCR. Unpublished Masters Dissertation, Institut Universitaire Kurt Bosch, Switzerland. Retrieved from www.vdbio.ch/download/konflictmanagement/thesis_final_180209. Accessed 20/9/2012.

Chaudhry, A.M. \& Asif,R.(2015). Organizational Conflict and Conflict Management: a synthesis of literature. Journal of Business and Management Research, 9, 238-244.

Dana, D. (2001). The Dana measure of financial cost of organisational conflict, retrieved from http://www.mediationworks.com. Accessed 13/9/2015.

Dayal, I., \& Thomas, J. M. (1968). Operation KPE: Developing a new organization. Journal of Applied Behavioral Science, 4, 473-506.

De Dreu, C. K. W., \& Gelfand, M. J., (2007). Conflict in the workplace: sources, dynamics, and functions across multiple levels of analysis. In C. K. W. De Dreu, \& Gelfand, M. J. (Ed). The Psychology of Conflict and Conflict Management in Organisation, 3-54. London: Lawrence Erlbaum Associate.

De Dreu, C. K., \& Weingart, L. R. (2003). Task versus relationship conflict, team performance, and team member satisfaction: a meta-analysis. Journal of applied Psychology, 88(4): 741-749. 
Deutsch, M., Coleman, P. T., \& Marcus, E. C. (2006). The handbook of conflict resolution: theory and practice (2nded), Jossey- Bass, United States of America.

Deutsch, M. \& Coleman, P. (2000). (eds.). The handbook of conflict resolution: Theory and practice. San Francisco: Jossey-Bass.

Dewey, J. (1957). Human nature and conduct. New York: Modern Library. [originally published 1922]

de Wit, F. R., Greer, L. L., \& Jehn, K. A. (2012). The paradox of intragroup conflict: a metaanalysis. Journal of Applied Psychology, 97(2): 360-390.

Dyr, W. G. (1987). Team building: Issues and alternatives (2nd ed.). Reading, MA: AddisonWesley.

Fajana (2000). In Bernard Oladosu Omisore,B.O\& Ashimi Rashidat Abiodun,A.R.(2014). Organizational Conflicts: Causes, Effects and Remedies. International Journal of Academic Research in Economics and Management Sciences , 3( 6): 118-137.

Fisher, R.J. (1997). Interactive conflict resolution. NY: Syracuse University Press.

Gist, M. E., Locke, E. A., \& Taylor, M. S. (1987). Organizational behavior: Group structure, process, and effectiveness. Journal of Management, 13, 237-257.

Goldman, A. L. (1991). Settling for more: Mastering negotiating strategies and techniques. Washington, DC: Bureau of National Affairs.

Hackman, J. R., \& Oldham, G. R. (1980). Work redesign. Reading, MA: Addison- Wesley.

Herzberg, F., Mausner, B., \& Snyderman, B. (1959). The motivation to work. New York: Wiley.

Jehn (1999). In Omisore, B.O\& Abiodun, A.R. (2014). Organizational Conflicts: Causes, Effects and Remedies. International Journal of Academic Research in Economics and Management Sciences, 3( 6): 118-137.

Jehn, K. A. (1997). A qualitative analysis of conflict types and dimensions in organizational groups. Administrative Science Quarterly, 42, 530-557

Jehn, K. A. (1995). A multimethod examination of the benefits and detriments of intragroup conflict. Administrative science quarterly, 256-282.

Jehn, K. A., \& Bendersky, C. (2003). Intragroup conflict in organizations: A contingency perspective on the conflict-outcome relationship. Research in organizational behavior, $25,187-242$.

Jehn, K. A., Clint,C. \&Sherry, T. (1997). To agree or not to agree: Diversity, conflict, and group outcomes. International Journal of Conflict Management, 8: 287-306. 
Jehn, K.A. \& Mannix, E. (2001). The Dynamic Nature of Conflict: A Longitudinal Study of Intra-group Conflict and Performance. Academy of Management Journal, 44(2), 238-251.

Jehn, K.A., Northcraft, G. B., \& Neale, M. A. (1999). Why some Differences Make a Difference: A Field Study of Diversity, Conflict and Performance in Workgroups. Administrative Science Quarterly, 44 (4):741-763.

Kabanoff, B. (1991). Equity, Equality, Power and Conflict. Academy of Management Review, 16 (2): 416-441.

Laue, J. (1992). The emergence and Institutionalisation of third party roles in conflicts: In Dannis J. D. Sandole and Ingrid Sandole-Staroste (eds); Conflict Management and Problem Solving: Interpersonal to International Application, New York: New York

Lawrence, P. R., \& Lorsch, J. W. (1967a). Differentiation and integration in complex organizations. Administrative Science Quarterly, 12, 1-47.

Lewicki, R. ,Saunders, D., Barry,B. (2009). Negotiation. 6th ed. New York: McGraw-Hill/Irwin.

Murnigham, J.K. \& Conlon, D.E. (1991). The Dynamics of Intense Workgroups: A study of British Sting Qualets. Administrative Science Quarterly, 36, 165-186.

Nelson, R. E. (1989). The strength of strong ties: Social networks and intergroup conflict in organizations. Academy of Management Journal, 32, 377-401.

Pinkley, R. L. (1990). Dimensions of conflict frame: Disputant interpretations of conflict. Journal of applied psychology, 75, 117.

Pondy, L. R. (1967). Organizational conflict: Concepts and models. Administrative Science Quarterly, 12, 296-320.

Rahim, M.A., (2010). Managing conflict in organization (3rded) London: Quorum Books.

Rahim, M. A.(2001). Managing conflict in organizations. $3^{\text {rd }}$ Ed. London: Greenwood Publishing Group, Inc.

Rahim, M. A., \& Bonoma, T. V. (1979). Managing organizational conflict: A model for diagnosis and intervention. Psychological Reports, 44, 1323-1344.

Ramani, K., \& Zhimin, L., (2010). A Survey of conflict resolution mechanisms in public secondary schools: A case of Nairobi Province, Kenya, Educational Research Reviews, 5(5), 242-256.

Riaz, M. K., \& Junaid, F. A. (2011). Types, sources, costs and consequences of workplace conflict. Asian Journal of Management Research, 2(1), 600-611.

Robbins, P. S. \& Judge, A.T. (2013). Organizational Behavior, $15^{\text {th }}$ Ed., Pearson, NY.USA.

Simons, T. L., \& Peterson, R. S. (2000). Task conflict and relationship conflict in top management teams: the pivotal role of intragroup trust. Journal of applied psychology, 85(1), 102. 
International Journal of Advanced Academic Research (Social and Management Sciences) | ISSN: 2488-9849

Journal DOI: 10.46654/ij.24889849

Vol. 6, Issue 10 (October, 2020) | www.ijaar.org

Article DOI: 10.46654/ij.24889849.s61010

Tjosvold, D.; Dann, V.\& Wong,C. (1992). Managing Conflict Between Department to Serve Customers. Human Relations, 45 (10): 1035-1054.

West, W.A. \& Anderson, N.R. (1996). Innovation in to Management Teams. Journal of Applied Psychology, 81 (6), 680-693.

Wise, T. (2000). Conflict in the church: workbook, Trinity College \& Seminary.

Wlodarczyk, A. Z. (2010). Work Motivation: A Systemic Framework for a Multilevel Strategy. USA: Author House. 